Article

\title{
Green Jack: Naïveté, Frontier and Ecotopia in On the Road
}

\author{
Michael Amundsen
}

Citation: Amundsen, Michael. 2021. Green Jack: Naïveté, Frontier and Ecotopia in On the Road. Humanities 10: 37. https://doi.org/10.3390/ h10010037

Received: 19 January 2021

Accepted: 22 February 2021

Published: 26 February 2021

Publisher's Note: MDPI stays neutral with regard to jurisdictional claims in published maps and institutional affiliations.
School of Humanities, Arts and Cultural Studies, Arizona State University, Glendale, AZ 85306, USA; michaelamundsen@asu.edu

\begin{abstract}
Jack Kerouac's On the Road is among the seminal texts of the Beat Generation canon, and the author himself is renowned as a hero of American letters and freedom. Kerouac's book is clearly one of the most inspirational of the last century and helped to spur the culture of mobility, spiritual yearning and adventure in the decades following its release not only in the USA but in many other parts of the world. A close reading of On the Road reveals other realities about the author, through his character Sal Paradise, and the America he discovers in his travels. This article looks at the files from Kerouac's aborted stay in the US navy, letters, journal entries and the text of On the Road itself to demonstrate that the author's Whitmanesque longings and ennui are very much rooted in a romantic vision challenged by the realities of mid-20th-century American life. However, Kerouac's "ecotopia of the West" also suggests other ways of living which would influence America's counterculture and environmental movements.
\end{abstract}

Keywords: Kerouac; On the Road; frontier; ecotopia

\section{Introduction}

On the Road is a seminal text of the Beat Generation, part of the early foundational legends of the movement along with Allen Ginsberg's Howl and William Burroughs' Naked Lunch. Its author, Jack Kerouac, is a heroic figure to millions around the world, including giants of art and popular culture such as Bob Dylan, David Bowie and members of the Grateful Dead, as an exemplar of freedom.

On the Road is a revealing text on many levels. The first glimpse the American mass reading public got of the nascent Beat Generation milieu came from this book. Neal Cassady, Allen Ginsberg and William Burroughs (Dean Moriarty, Carlo Marx and Old Bull Lee, respectively) found their way into the American consciousness through reading On the Road. All reached legendary status in their lifetimes. The fact that Kerouac wrote about friends who became famous cultural figures is something of a miracle, in keeping with the novel's hagiographic tone in respect to Neal Cassady and its outsized influence on the young people who have read it around the world for more than 60 years.

Figuring On the Road in the life of the author is an intriguing exercise. Because it took so long to get published, when On the Road finally appeared in 1957, it was the work of a much younger man. Kerouac was 35 when On the Road first found its way into the bookshops, hands of reviewers and readers. He was on the cusp of a decline which led to his death 12 years later as a bitter drunk living with his mother in Florida. This is the Kerouac people wish to forget and, aside from biographies, the last years of his life tend to be ignored by scholars.

However, alienation, as much as adventure and freedom figure prominently in Kerouac's oeuvre. On the Road has been seen as a Whitmanesque love letter to America and certainly the book features some of this sentiment. These are also the parts of the novel which have come in for criticism. The kind of "forced" feeling for the everyday people and societal flotsam that, aside from Kerouac's friends, appear in the novel. Kerouac's search for the numinous in the commonplace is a striking feature not only of On the Road but of 
Beat Generation literature broadly. However, there is much disappointment in the voice of the author through his narrator Sal Paradise.

Kerouac struggled with aspects of his mental health throughout his life, most notably his alcoholism. The author was aware as well of his dual nature, one that required at least as much solitude as traveling adventures. Kerouac noted in himself a kind of split personality in a letter to a friend around the time of his brief sojourn in the United States navy:

"My mind, split up, as it were, in two parts ... the bent and brooding figure sneering at a world of mediocrities, complacent ignorance, and bigotry exercised by ersatz Ben Franklins, the introverted, scholarly side; the alien side ... My normal counterpart, the one you're familiar with, is the half-back-whoremasteralemate-scullion-jitterbug-jazz critic side, the side in me which recommends a broad, rugged America; which requires the nourishment of gutsy, redblooded associates; and which lofts whatever guileless laughter I've left in me rather than that schizoid's cackle I have of late."

(Kerouac 1995)

The second half of this quote is redolent of Jack London's butch hyperbole, his work The Road being an inspiration for Kerouac's similarly titled work. The reflexive Kerouac understood his inconsistencies, the quiet scribe and the macho action man, the successful synthesis of which was personified in the shining intellect and wild adventures of On the Road's hero, Dean Moriarty. It was the inconsistencies of America which the author found hardest to reconcile. In this paper, I do not equate Sal Paradise and Jack Kerouac. Sal Paradise is a literary creation from the imagination of the author. Nicosia (1983), for example, has noted biographical differences in Kerouac's relationships as depicted in On the Road and experienced in his life, including with Neal Cassidy. In addition, we know that even straight autobiographies are necessarily selective and not exclusive representations of facts. However, there is much of Kerouac in Sal. The naiveite, romanticism and disappointments of Sal Paradise are mirrored in letters, journal entries and the experiences of the author in his short-lived stint in the US navy.

\section{Ecotopia and On the Road}

In the general sense, a "green" society is one we can live and thrive in. It is "clean", conducive to health mental and physical and promotes both the need for human striving and coexistence with other life forms which is harmonious. Though Kerouac's work The Dharma Bums more explicitly deals with notions of consumption, right living and nature, $O n$ the Road, as a foundational text of the counterculture, lends itself to ideas of utopian visions.

The term utopia goes back to Thomas More's work Utopia: a little, true book, not less beneficial than enjoyable, about how things should be in a state and about the new island Utopia. More's book, published in 1516 in Latin, was a political satire about a new world kingdom's ideal society; the neologism "utopia" was coined in this work and is derived from Greek, meaning literally "nowhere".

Likewise, the term ecotopia is a neologism coined by an author for the purpose of a novel, in this instance Ecotopia: The Notebooks and Reports of William Weston by Ernest Callenbach, a work of utopian fiction with an emphasis on environment and society. In this instance, the coined word is not "nowhere", but somewhere very specific. "Eco" comes from the Greek oikos for household or home and "topia" from the Greek "topos" or "place". In this sense the term ecotopia is very apropos for the quest of Sal Paradise in Kerouac's novel, as Sal seeks the meaning of his home, that is, America, and his place in it.

It has been noted that utopian visions lead to an ecological point of view, of how society and nature can be arranged more harmoniously (Holquist 1968, p. 113). On the Road can be read from many different perspectives but it is not explicitly a "green" book expressing environmental concerns. It does, however, obviously and implicitly critique aspects of American life related to ecology and notions of place. These related themes include freedom, authenticity and lifestyle. In common with much utopian literature, Kerouac expresses 
in On the Road that simpler and more physical ways of living, a precursor to the "back to nature" perspective he explores in The Dharma Bums, are preferable to urban, intellectual life. Kerouac's hero Sal hopes to discover these lifeways in the West.

More and Callenbach's vision has been described as pastoral and romantic (McCutcheon 1995, p. 152). Kerouac's ecotopia is likewise oriented. One of the ways in which Kerouac challenges dominant notions of mid-20th-century American life in On the Road is through a differing appreciation of time (Mortenson 2001). The "corruption of time" through the dictates of economic practice, where the worker punches a clock and spends the majority of their waking hours involved in alienated labor, stands in opposition to Kerouac's ecotopian vision of self-directed action, adventure and work as a means to living not consuming. This type of work is frequently lionized in On the Road as physical and performed in rural settings.

However, in many ways On the Road chronicles a picaresque quest seeking transcendence. Kerouac's character's name speaks to this. Sal Paradise can be said to be an immigrant like Kerouac with an ethnic name. "Salvatore" is an Italian name meaning savior, a reference to Kerouac's basic worldview as a Catholic. Paradise is what Sal and his friends seek in their frenetic travels, an ecotopia of self-understanding where the American landscape and its possibilities are realized. This kind of searching after personal and spiritual truths inspired the idealistic mindset of the hippies which included environmentalism, not the mere conservationism of the progressive element of their American forebearers. Conservationists wish to protect nature through set asides like national parks. Environmentalists seek a wholly new or perhaps syncretic and very old way of relating to the natural world as humans.

But was Kerouac an "environmentalist"? The evidence suggests he was not. Kerouac was derisive of hippies, referring to them as "parasites" and, though it is wrong to conflate environmentalism and the hippie youth movement, they broadly overlap under the banner of counterculture of which Kerouac is rightly or wrongly the godfather (Kerouac 1969). This can be understood as one of the many paradoxes in Kerouac's relationship with American cultural life. Less an environmentalist, Kerouac was an old-fashioned urban bohemian who held more in common with Baudelaire and Poe than Emerson and Thoreau. This stance towards life put him at odds with the work/consume paradigm underpinning American society making him at once a kind of subversive and friend of nature that could appeal to a broad swath of philosophies. His flaneuring in cities became gasoline-fueled improvised expeditions with Neal Cassady.

The Beats certainly drew inspiration from Thoreau, Emerson and the 19th century transcendental movement in their own utopian quests. Ginsberg, in particular, turned to his "transcendental predecessors articulating a mystical impulse to drop out from the 'moral' restraints of modern society, restoring ways of being defined in and through an always already sense of togetherness, of community" (Shipley 2013, p. 233). From this perspective, it is Ginsberg who can be more rightly ascribed as the founder of the American counterculture and its utopian vision. Kerouac, the keen individualist, is an unlikely candidate for communalism of any kind. However, of the original triumvirate of Beat figures, Kerouac, Ginsberg and Burroughs each in their own way drew on the transcendental tradition which includes attention to environmental concerns. Kerouac and Ginsberg celebrate the American landscape a la Whitman, whereas Burroughs' commitment to "direct action" aligns him with Thoreau's anti-government Civil Disobedience (Weidner 2016, p. 12). Burroughs' obsession with firearms and his marijuana farming shows a Beat affinity for ruralism and libertarianism. At the stage of Burroughs' life described in On the Road, as the character Old Bull Lee, we also have an example of dropping out of square society which became an important part of the American counterculture ethos. For the Beats, traditional notions of American freedom are often approached through non-traditional or emerging cultural vantage points from drug use, to alternative lifestyles, to Buddhism (Garton-Gundling 2017, p. 200). 
The feeling of the reader of On the Road is that Kerouac wants to be a Thoreau, finding transcendence, as in The Dharma Bums, he wants to be Han Shan, a crazy wise poet living on a mountain top. He wants to love America, its landscape and people. He wants to love the authentic and true America like the romantic that he was. He strives to be a modern Walt Whitman, but the world he encounters differs from his naïve hopes. Kerouac's record as a failed navy recruit, his journal entries and the text of On the Road show the internal and external paradoxes of the man and his country. However, Kerouac's critique of assumptions about American life pointed to new potentials and orientations including environmentalism. The writings of the Beat Generation have long been seen as a space of cultural and political contestation (Haslam 2009, p. 444). Though the Beats have been appreciated as largely an urban phenomenon living outside social, sexual, religious and political norms, this oppositional stance fed America's green movement. For Kerouac, freedom is at the center of his ecotopia as well as a naïve appreciation of the concept of frontier.

\section{Kerouac as Frontiersman}

On the Road makes much of the difference between East and West in the United States. For Kerouac, the East, represented by his stay at Columbia University, is New York City and effete intellectualism. The West is open spaces, freedom and physicality. The personification of the West is Dean Moriarty, as Sal Paradise says, "A western kinsman of the sun, Dean."

However, Sal Paradise had never been to the West. "I'd often dreamed of going West to see the country, always vaguely planning and never taking off." So, his understanding of the West is derived from his own imagination and his meeting with Dean Moriarty, who he first encounters in New York. Sal Paradise idolizes Dean and conflates his qualities with the West of his dreams and the one he hopes to discover. "My first impression of Dean was of a young Gene Autry-trim, thin-hipped, blue-eyed, with a real Oklahoma accent-a sideburned hero of the snowy West. In fact he'd just been working on a ranch, Ed Wall's in Colorado, before marrying Marylou and coming East." (Kerouac 1957, p. 2).

How much Sal Paradise can be conflated with Jack Kerouac is a matter of debate. However, the original version of $O n$ the Road used the actual names of the protagonists. Kerouac's letters and journal entries mirror the naivete of the novel's narrator. The reader can assume there is much similarity between them, while allowing that Kerouac was also an intelligent man and fine writer who knew what he was writing and the kind of authorial voice he was projecting. The puerile idealism of Sal Paradise is demonstrated in an unmailed letter Kerouac wrote about the time he entered the US Navy in 1943.

For one thing, I wish to take part in the war, not because I want to kill anyone, but for a reason directly opposed to killing-the Brotherhood. To be with my American brother, for that matter, my Russian brothers; for their danger to be my danger; to speak to them quietly, perhaps at dawn, in Arctic mists; to know them, and for them to know myself ... I want to return to college with a feeling that I am a brother of the earth, to know that I am not snug and smug in my little universe.

(Kerouac 1995)

The sort of sweet absurdity of this note shows that the romantic Kerouac was the real Mccoy, not just a literary contrivance. So, as strange as it may seem to modern readers or for a book produced in 1957, the author is apparently convinced on some level that a freebooting frontier is still to be found out there in the "West".

Here, it may be useful to take a short historical detour. Historian Frederik Jackson Turner stated in his famous Frontier Thesis of 1893 that the American frontier had in fact ended as a reality in 1890. He quotes the superintendent of the census from that year. "Up to and including 1880 the country had a frontier of settlement, but at present the unsettled area has been so broken into by isolated bodies of settlement that there can hardly be said to be a frontier line. In the discussion of its extent, its westward movement, etc., it can not, 
therefore, any longer have a place in the census reports." Turner believed that the strength and vitality of the America identity lay in its land and vast frontier. Turner stated the traits of the frontier are "coarseness and strength combined with acuteness and inquisitiveness." (Turner 1893). In America, there is "dominant individualism, working for good and for evil, and withal that buoyancy and exuberance which comes with freedom." The end of the American frontier called its future developments and institutions into question.

In Turner's statement can be seen the one part of Kerouac's personality, his physical "half-back", "whoremaster" side and also the person of Dean Moriarty. The red-blooded frontiersman may live on in Sal and Dean, but the frontier is missing, which in part explains the quixotic nature of their journey.

For Sal Paradise, the frontier equals the "real America". The real America in On the Road is encountered not as much in the country's landscapes and "frontiersmen" but in offbeat fringe characters, everyday people in commonplace settings like diners, in his scattershot artistic friends and the vague hope of the road, of what might be around the next turn. The improvised nature of Sal and Dean's travels is evident in their quest for transcendence. As Dean Moriarty says:

"Sal, we gotta go and never stop going 'till we get there."

"Where we going, man?"

"I don't know but we gotta go."

The holy grail of "there" does involve frontiers but perhaps not those initially envisioned by Sal Paradise or Jack Kerouac. When the travelling cohort traverses the frontier with Mexico, this is a seminal and threshold moment, of before and after, inauthentic and authentic. Likewise, the transcendence of experiencing jazz music performed by black Americans is a frontier between the prosaic and the fantastic. Dean Moriarty is a frontier between square society and yea-saying, life-affirming reprobation. The frontier is the margins of society or in a different society altogether.

On the Road also finds Sal Paradise reaching the margins in himself. In a very telling passage, the novel's narrator crosses a boundary and finds himself in a liminal state. Sal's fragile personality and sense of self are conflated with a specific geographic locale, the middle of America, and his westward movement:

I wandered down to the railroad tracks-and there're a lot of them in Des Moinesand wound up in a gloomy old Plains inn of a hotel by the locomotive roundhouse, and spent a long day sleeping on a big clean hard white bed with dirty remarks carved in the wall beside my pillow and the beat yellow windowshades pulled over the smoky scene of the rail-yards. I woke up as the sun was reddening; and that was the one distinct time in my life, the strangest moment of all, when I didn't know who I was-I was far away from home, haunted and tired with travel, in a cheap hotel room I'd never seen, hearing the hiss of steam outside, and the creak of the old wood of the hotel, and footsteps upstairs, and all the sad sounds, and I looked at the cracked high ceiling and really didn't know who I was for about fifteen strange seconds. I wasn't scared; I was just somebody else, some stranger, and my whole life was a haunted life, the life of a ghost. I was halfway across America, at the dividing line between the East of my youth and the West of my future, and maybe that's why it happened right there and then, that strange red afternoon.

(Kerouac 1957, p. 11)

\section{The State of Jack and the Navy Prognosis}

In 2005, the National Personnel Records Center released extensive files on Jack Kerouac's time as a failed naval recruit during World War II. The records are quite revealing of the young man who would go on to write On the Road based upon experiences that would soon come to pass. Kerouac initially wanted to be a naval aviator, and though 
he performed well on intellectual tests and had glowing recommendations from former authority figures in his life he was found unsuited for flying.

This was just the beginning of Kerouac's naval failure. During his initial examination in the spring of 1943, he was considered sufficiently abnormal to be given trial duty status. After 10 days of basic training, he was sent to the hospital because of headaches and an unsuitable disposition including restlessness, apathy and the need for seclusion. It was then that his psychiatric examination began.

The navy doctor's neuropsychiatric examination disclosed auditory hallucinations, ideas of reference and suicide, and a rambling, grandiose, philosophical manner. Diagnosed with dementia praecox (schizophrenia), Kerouac was sent to the Naval Hospital in Bethesda, Maryland (Kleiman 2011). There he went through thorough interviews about his life history and relationships.

Kerouac's naval experience provides a window into the mindset of a shiftless young man who seems to be throwing his promise away. A gifted athlete, he quit playing football. A gifted student, he dropped out of prestigious, Ivy League, Columbia University. Now, a washout as a navy recruit, where even average people are expected to succeed, Kerouac seemed to be hitting bottom. His naval interlocutors were very intrigued by his self-styled occupation of "writer". At the time, Kerouac was unpublished, which did not add credence to his artistic credentials. He had, however, done quite a bit of writing by this stage of his life, including three novels and endless journal entries. He was, in fact, a writer and had been all his life. The navy saw this as "delusions". They considered his occupation as "writer" further evidence of his mental imbalance. This can be considered an early example of the Beat Generation encountering the obstinacy and incomprehension of an official bureaucracy. Kerouac's interviewers were hard pressed to understand the sort of man they were dealing with and his perspective as an artist.

Patient describes his writing ambitions. He has written several novels, one when he was quite young, another just prior to joining the service, and one he is writing now ... patient states he believes he might have been nervous when in boot camp because he had been working too hard just prior to induction. He had been writing a novel, in the style of James Joyce, about his own home town, and averaging approximately $16 \mathrm{~h}$ daily in an effort to get it down. This was an experiment and he doesn't intend to publish. At present he is writing a novel about his experiences in the Merchant Marine. Patient is very vague in describing all these activities. There seems to be an artistic factor in his thinking when discussing his theories of writing and philosophy.

(Kleiman 2011)

Kerouac noted his inability to adapt to military life. In concord with the transcendentalists, the integrity of independent perspective and conscience is foremost in his thinking. He found in his naval experience a constitutional incompatibility with military discipline, explaining the situation this way:

Independent thought ... now go ahead and put me up against a wall and shoot me, but I stand by that or stand by nothing but my toilet bowl, and furthermore, it's not that I refuse Naval discipline, not that I wont take it, but that I CANNOT. This is about all I have to say about my aberration. Not that I wont, but that I cant.

(Kerouac 1967)

The navy's final diagnosis was a constitutional psychopathic state, schizoid personality. The navy doctors noted he bordered upon but had not reached psychosis. In all, Kerouac spent around five months in the navy, almost all of it hospitalized. In between interviews, he had much time to consider his situation and plans. His stance against authority and for art crystalized at this time. Kerouac's stubborn independence and need for freedom was the seed of his ensuing lifestyle and creativity. The episodic hedonism of On the Road was 
already on his mind. As Kerouac noted at the time, "Each debauchery is a private though short-lived insurgence from the static conditions of his society."

\section{Green Jack}

There is much to glean from a green reading of On the Road which illuminates the author and Sal Paradise's understanding of the America he is discovering while he discovers himself. Kerouac's romantic approach to living emphasizes emotional life and experience. The feelings of Sal Paradise are projected onto the landscapes he encounters. Sal loved the Mississippi River before he ever saw it, an aspect of the narrator's imaginative understanding of his homeland, a conception that would be challenged on his journey. The author conveys a strong sense of the phenomenology of place in this passage:

And here for the first time in my life I saw my beloved Mississippi River, dry in the summer haze, low water, with its big rank smell that smells like the raw body of America itself because it washes it up. Rock Island-railroad tracks, shacks, small downtown section; and over the bridge to Davenport, same kind of town, all smelling of sawdust in the warm midwest sun. Here the lady had to go on to her Iowa hometown by another route, and I got out.

(Kerouac 1957, p. 9)

The author tends to see the environment in the context of human relationships and civilization. Kerouac's view is very much anthropocentric in contrast to a writer like Gary Snyder, who celebrates nature for its own sake and who could easily envisage a world without humans at all. Of all the writers associated with the Beat Generation, it is perhaps Snyder who has most systematically envisioned and lived an ecotopia of right living in an ethical communion with the natural world. As Snyder says, "And I would like to think of new definition of humanism and a new definition of democracy that would include the nonhuman, that would have representation from those spheres. This is what I think we mean by an ecological conscience." (Snyder 1974, p. 106).

Kerouac commiserates with people and things, often with a sense of sadness and pity, whereas Snyder empathizes with the natural world and its creatures in a way that underscores agency, autonomy and the ethical right to exist unfettered from human control. In terms of Kerouac's development in his relationship to nature, On the Road is a prequel to The Dharma Bums where Kerouac figures Snyder, through the character of Japhy Ryder, as the novel's hero whose attitudes he strives to emulate, something he fails to achieve.

For Sal Paradise, the natural world is one more thing to "dig", another sensual experience or source of kicks. When Sal, Dean and Stan get to Mexico, they experience a "new tropic" air and landscape. Again, Sal commiserates with a place and feels novel sensations. Sal and the heavy, tropical atmosphere become one:

Still there was no breeze, but the steel had an element of coolness in it and dried my back of sweat, clotting up thousands of dead bugs into cakes on my skin, and I realized the jungle takes you over and you become it. Lying on the top of the car with my face to the black sky was like lying in a closed trunk on a summer night. For the first time in my life the weather was not something that touched me, that caressed me, froze or sweated me, but became me. The atmosphere and I became the same. Soft infinitesimal showers of microscopic bugs fanned down on my face as I slept, and they were extremely pleasant and soothing. The sky was starless, utterly unseen and heavy. I could lie there all night long with my face exposed to the heavens, and it would do me no more harm than a velvet drape drawn over me. The dead bugs mingled with my blood; the live mosquitoes exchanged further portions; I began to tingle all over and to smell of the rank, hot, and rotten jungle, all over from hair and face to feet and toes.

(Kerouac 1957, p. 185)

The reader also feels in On the Road that the author's search for authenticity is tantamount to a patriotic duty. After all, it is the work of young people in all societies to uphold 
tradition, to preserve and carry forward meaningful aspects of culture life. In his travels west, Sal Paradise finds some of what he hoped was still part of American life. Sal espies a cowboy, for him a semiotic of his imaginative "true" West:

"We arrived at Council Bluffs at dawn; I looked out. All winter I'd been reading of the great wagonparties that held council there before hitting the Oregon and Santa Fe trails ... Then Omaha, and, by God, the first cowboy I saw, walking along the bleak walls of the wholesale meat warehouses in a ten-gallon hat and Texas boots ..."

(Kerouac 1957,p. 17)

Wagon parties holding councils also speaks to notions of American democracy and egalitarianism. Finding value in common people is certainly paramount in Sal's consciousness. In this instance, Kerouac conjures up a past of direct democracy, common purpose and the right kind of community which stands in contrast to a plutocracy of elites and anonymous bureaucracies.

Sal also finds deep continuity in the landscapes he encounters for the first time. Like an anthropologist, he gains local knowledge from the informants he encounters. The valley of the river Platte is "almost" as great as the Nile's, and for Sal, the American pastoral becomes at once exotic, familiar and epic:

We got off the bus and walked clear up the hill, the long hill formed over the millenniums by the mighty Missouri, alongside of which Omaha is built, and got out to the country and stuck our thumbs out. We got a brief ride from a wealthy rancher in a ten-gallon hat, who said the valley of the Platte was as great as the Nile Valley of Egypt, and as he said so I saw the great trees in the distance that snaked with the riverbed and the great verdant fields around it, and almost agreed with him.

(Kerouac 1957, p. 17)

However, the novel's narrator also discovers blandness and sameness in his westward movements. He admits the "first cowboy he ever saw" looked like any "beat character of the brickwall dawns of the East except for the getup." And of Council Bluffs he says, "of course now it was only cute suburban cottages of one damn kind and another, all laid out in the dismal gray dawn."

If Sal finds sensuality, late in the novel in the Mexico passages especially, as perhaps the most genuinely meaningful parts of his journey, this is symbolic of a kind of capitulation, of admitting that hedonism is his path forward to transcendence. Though Sal Paradise makes much of the West and its decent genuine people, the Mexican parts of On the Road reveal an excited young man eager for life, whereas the "forced" appreciation of "western" things shows itself earlier in the story. Throughout his novel, Kerouac valorizes common people, especially rural men of the soil:

I heard a great laugh, the greatest laugh in the world, and here came this rawhide old-timer Nebraska farmer with a bunch of other boys into the diner; you could hear his raspy cries clear across the plains, across the whole gray world of them that day. Everybody else laughed with him. He didn't have a care in the world and had the hugest regard for everybody. I said to myself, Wham, listen to that man laugh. That's the West, here I am in the West. He came booming into the diner, calling Maw's name, and she made the sweetest cherrypie in Nebraska, and I had some with a mountainous scoop of ice cream on top.

(Kerouac 1957, p. 19)

A guffawing loudmouth in overalls could be seen as repellent to many people, but for Sal it is a sign of the West, of authenticity. He wants to believe. He even has some cherry pie with ice cream. Sal then makes the dubious claim, "I wished I knew his whole raw life and what the hell he'd been doing all these years besides laughing and yelling like that." 
We can see that Sal's idea of ecotopia is inherently linked to people and landscapes. People working the land, farmers, cowboys, laborers, in some kind of balance with nature, a friendly place. As a perpetual stranger, friendliness is important for Sal not only for companionship but for hitching rides and learning the lay of the land. Sal relies on the charity of others. This accessibility and openness are a part of his ecotopian vision of the West. Guffawing men and overalls represent this vision. As does a wholesome slice of cherry pie, the ingredients for which were no doubt grown right there in the local soil.

However, Sal is quickly confronted with a caricature of his ecotopian vision as he travels westward. He enters Cheyenne, Wyoming with Montana Slim who was just his traveling companion in the back of a pickup truck. It was Wild West Week in Cheyenne with everyone emulating what they thought the real wild west was like, no doubt informed by Hollywood movies. Sal's fragile ecotopia is starting to fray.

"Farther down were the long stringy boulevard lights of new downtown Cheyenne, but the celebration was focusing on Oldtown. Blank guns went off. The saloons were crowded to the sidewalk. I was amazed, and at the same time I felt it was ridiculous: in my first shot at the West I was seeing to what absurd devices it had fallen to keep its proud tradition."

(Kerouac 1957, p. 30)

Sal comes to realize that the West of his dreams was a callow illusion. Western traditions had been commoditized, overrun by parody and "progress". On this point, Kerouac and environmentalists find concord. Both are dubious of progress' benefits for living well. The post-war interstate highway system was what brought Sal West on his adventures but also what brought the homogenization of American culture. Getting from New York to Wyoming by wagon would have been slower, harder and surely would have provided less kicks. However, it would have been authentic. Perhaps a little too authentic. Kerouac liked urban life, its nightclubs, jazz music, girls and booze. So again, this shows a split in his personality; the seeker after the authentic and the seeker of convenience, pleasure and comfort. The Dharma Bums brought this conflict into bold relief. Being a fire lookout in the wilderness was not easy on Kerouac.

Kerouac's notion of ecotopia in On the Road is closely tied to his understanding of Oswald Spengler's notion of the fellaheen. Here is timeless authenticity, regardless of political or economic change. Spengler, in his The Decline of the West, describes the fellaheen as those on society's margins, unchanging and individually a "ranging animal, a being whose waking consciousness restlessly feels its way through life, all microcosm" (Spengler 1918, p. 89). The boisterous farmer is a fellaheen, as is the Mexican peasant, the black jazz musician and, importantly, Dean Moriarty. Both Kerouac and Ginsberg portrayed Neal Cassady in prose and poetry as a near mythological person and exemplar of life lived to its fullest. Cassady's life story, charisma and abilities were connected with Spengler's description of the essential fellaheen type (Lardas 2001, p. 125).

For Sal, Dean Moriarty promised something better than intellectualism-joy: the pursuit of unfettered sensory and sensual experience; apolitical, amoral, unstructured. Moriarty feels his way through life, improvising, "digging" what is there to be dug. In the author's imagination and theoretical category, he is Spengler's fellaheen, living in the moment, free of the bonds of ordinary work and home-life (Amundsen 2015). The inspiration for the hippie counterculture is evident in this worldview. This is Kerouac's real ecotopia: freedom.

\section{Conclusions}

George Bernhard Shaw famously wrote in his play Man and Superman, "The reasonable man adapts himself to the world: the unreasonable one persists in trying to adapt the world to himself. Therefore, all progress depends on the unreasonable man." Jack Kerouac was noted throughout most of his life as a kind and amiable person. However, he also was just such an unreasonable man as described by Shaw. His inability to adapt to America's establishment and nodes of power shows this unreasonableness. He could not adjust him- 
self to naval discipline. He dropped out of one of America's most prestigious universities. In the booming post-war American economy, the handsome intelligent Kerouac could have easily courted success, happiness, marriage and domesticity. A reasonable man would have done these very things. He did not. Kerouac, the seeker after truths beyond material wellbeing, hit the road instead to discover life for himself. The world has not been the same since. The influence of On the Road persists to this day.

Part of Kerouac's unreasonableness was a stubborn naivete. His correspondence and journal entries reveal a romantic sensibility which finds resonance in On the Road's narrator, Sal Paradise. Societal change often comes from the margins, and this was precisely the stuff of Kerouac's fiction. Indeed, Kerouac adapted the world to himself with the great influence of his novels, especially On the Road. Though Kerouac clearly had issues with how his works were grafted on to the counterculture, he nudged America's youth to consider other ways of living aside from career and consumption. This was his greatest contribution to "green" America. Kerouac's artistic vision lends itself to utopian dreams.

For Jack Kerouac, an American ecotopia was a place of expansive freedoms of expression, action and movement. Sal Paradise personified both the hope and disappointment of this notion. There must be a place for freebooting life lovers in America. Sal figured this must be in the West, where people still were connected to the land, who, like the fellaheen, were people of the earth. They worked at places like Ed Wall's ranch out in Colorado, had real Oklahoma accents and were slim hipped and sideburned. They were yea-saying adventurers like Dean Moriarty. They were not intellectuals and they were not political.

This last point is important. Kerouac came to identify intellectualism as a malady. $\mathrm{He}$ saw life lived in the mind as not a life lived at all and came to appreciate the necessity of physicality and sensuality. Enter Neal Cassady, the embodiment of the physical life coupled with keen intelligence. Kerouac contrasted this "hero of the West" with his eastern friends, William and Jane Burroughs, Allen Ginsberg, Herbert Huncke and the like and found by comparison their worldview "negative". They were "theoretical", "sociological", "psychoanalytical" and very political. Cassady was as voracious for knowledge as for living. In this sense, he provided a ballast against Kerouac's eastern intellectual friends.

However, the West was not what he hoped for either. Kerouac's travels were hounded by homogenization and police surveillance. This led him to the conclusion that:

As far as I'm concerned the only thing to do is sit in a room and get drunk and give up your hoboing and your camping ambitions because there aint a sheriff or fire warden in any of the new fifty states who will let you cook a little meal over some burning sticks in the tule brake or the hidden valley or anyplace any more because he has nothing to do but pick on what he sees out there on the landscape moving independently of the gasoline power army police station-I have no ax to grind: I'm simply going to another world.

(Kerouac 1960)

And this is exactly how the last 10 years of his life played out. Kerouac became a committed alcoholic, living variously in Long Island and Florida, mostly drinking whiskey at home in front of the television, a lifestyle that killed him before he turned 50.

It is noteworthy that Kerouac's disenchantment with his life as a "writer" began long before his decline after the publication of On the Road. His first published novel The Town and the City was released in 1950 after a massive edit, cutting around 500 pages from the original manuscript, by Harcourt Brace under the auspices of Robert Giroux. Kerouac had high expectations for the book which sold poorly and from which he made little money, despite discussion of a movie deal. On the Road was already percolating in his mind and notebooks. However, he was left scarred by his ordeal in the business of writing. Kerouac still dreamed of the West.

It's about time for me to start working on On the Road in earnest. For the first time in ages, I want to start a new life. 
We-the whole family [Kerouac; his mother; his sister Nin; and her husband, Paul] —are going to move out to Colorado within a year. And within two years I'm going to marry a young lady. My aim is to write, make money, and buy a big wheat farm ... I stopped at a little shack where a man sold hot, red chili in paper containers. I bought some and ate it strolling in the dark, mysterious streets. I wished I was Negro, a Denver Mexican, or even a Jap, anything but a white man disillusioned by the best in his own "white world." (And all my life I had white ambitions!) ... anything but myself so pale and unhappy, so dim.

(Kerouac 1998)

Kerouac longed for the simple, meaningful life of the fellaheen tied to the soil and its basic pleasures, "a broad, rugged America" somewhere out West, the free West he discovered was so elusive.

Funding: This research received no external funding.

Institutional Review Board Statement: Not applicable.

Informed Consent Statement: Not applicable.

Data Availability Statement: Not applicable.

Conflicts of Interest: The author declare no conflict of interest.

\section{References}

Amundsen, Michael. 2015. On the Road: Jack Kerouac's epic autoethnography. Suomen Antropologi: Journal of the Finnish Antropological Society 40: 31-44.

Garton-Gundling, Kyle. 2017. Beat Buddhism and American Freedom. College Literature 44: 200-30. [CrossRef]

Haslam, Jason. 2009. It Was My Dream That Screwed Up: The Relativity of Transcendence in On the Road. Canadian Review of American Studies 39: 443-64. [CrossRef]

Holquist, Michael. 1968. How to play Utopia. In Game, Play, Literature. Edited by Jacques Ehrmann. Boston: Beacon Press, pp. 106-23.

Kerouac, Jack. 1957. On the Road. New York: Viking.

Kerouac, Jack. 1960. The Vanishing American Hobo. In Lonesome Traveller. New York: McGraw-Hill.

Kerouac, Jack. 1967. Vanity of Duluoz. New York: Penguin.

Kerouac, Jack. 1969. After me, the Deluge. Los Angeles Times, October 26.

Kerouac, Jack. 1995. Jack Kerouac: Selected Letters, 1940-1956. Edited by Ann Charters. New York: Penguin.

Kerouac, Jack. 1998. On the Road Again. The New Yorker. June 22. Available online: https:/ /www.newyorker.com/magazine/1998/06/ 22/on-the-road-again-jack-kerouac (accessed on 10 January 2021).

Kleiman, Miriam. 2011. Hit the Road, Jack! Prologue Magazine. Available online: https:/ /www.archives.gov/publications/prologue/ 2011/fall/kerouac.html (accessed on 12 January 2021).

Lardas, John. 2001. The Bop Apocalypse: The Religious Visions of Kerouac, Ginsberg and Burroughs. Urbana and Chicago: University of Illinois Press.

McCutcheon, Elizabeth. 1995. More's Utopia, Callenbach's Ecotopia, and Biosphere. Liber Amicorum 52: 149-70. [CrossRef]

Mortenson, Erik R. 2001. Beating time: Configurations of temporality in Jack Kerouac's On the Road. College Literature $28:$ 51-67.

Nicosia, Gerald. 1983. Memory Babe: A Critical Biography of Jack Kerouac. New York: Grove.

Shipley, Morgan. 2013. Hippies and the Mystic Way: Dropping Out, Unitive Experiences, and Communal Utopianism. Utopian Studies 24: 232-63.

Snyder, Gary. 1974. Turtle Island, with 'Four Changes'. New York: New Directions.

Spengler, Oswald. 1918. Decline of the West: Perspectives of World-History. London: Allen \& Unwin, vol. 2.

Turner, Frederick Jackson. 1893. The Significance of the Frontier in American History. Washington, DC: American Historical Association, Available online: http:/ / nationalhumanitiescenter.org/pds/gilded/empire/text1/turner.pdf (accessed on 11 January 2021).

Weidner, Chad. 2016. The Green Ghost: William Burroughs and the Ecological Mind. Carbondale: Southern Illinois University Press. 